\title{
Relationships Between and Within Physical and Chemical Constituents and in Vitro True Digestibility in Tropical Forage Grasses ${ }^{1}$
}

\author{
J. A. Arroyo-Aguilu and J. Coward-Lord ${ }^{2}$
}

\section{INTRODUCTION}

A knowledge of the relationships between and within parameters of chemical composition and nutritive value is of primary importance in evaluating forage grasses as they mature. This information is most necessary in the Tropics where the data are somewhat limited. The time-consuming and costly methodology of animal nutrition experimentation thus justifies the use of statistical analyses to estimate the corresponding correlation coefficients and equations to calculate the nutritive value of forages on the basis of their chemical composition.

\section{PROCEDURE}

Details of the experiment providing the data presented in this paper were described by Coward-Lord et al. $(6,7)$. Ten tropical forage grasses (Pangola, Digitaria decumbens; Congo, Brachiaria ruziziensis; Signal, Brachiaria brizantha; Buffel, Cenchrus ciliaris; Guinea, Panicum maximum; Jaragua, Hyparrhenia rufa; Giant Pangola, Digitaria valida; African Crab, Digitaria swazilandensis; Venezuelan Elephant, Pennisetum setosum; and Limpo, Hemarthria altissima), lightly fertilized with $\mathrm{NH}_{4} \mathrm{NO}_{3}$ at the rate of $350 \mathrm{~kg} / \mathrm{ha}$, were harvested by hand (machete) every 30 days up to 180 days of age. The samples were harvested from established $10 \mathrm{~m}^{2}$ plots at Mayagüez. Chemical analyses included: dry matter (DM), crude protein (CP), crude fiber (CF), ether-extract (EE) and ash (A) by the A.O.A.C. methods (4), and neutral-detergent fiber (NDF), acid-detergent fiber (ADF), permanganate lignin (L), cellulose (C), silica ( $\mathrm{Si}$ ) and in vitro true digestibility (IVTD) by the Goering and Van Soest's techniques (9). Nitrogen-free extract (NFE), neutral-detergent soluble (NDS) and hemicellulose $(\mathrm{H})$ were calculated by difference.

The data were subjected to simple and/or multiple correlation and/or regression analyses (17).

1 Manuscript submitted to Editorial Board November 2, 1973.

2 Associate Nutritionist, Agricultural Experiment Station, University of Puerto Rico, Rio Piedras, P.R., and Assistant Professor of Pastures, Animal Husbandry Department, Faculty of Agronomy, University of Costa Rica, San José, Costa Rica. 


\section{RESULTS AND DISCUSSION}

PHYSICAL AND CHEMICAL CONSTITUENTS

The most important factor influencing the chemical composition and digestibility of grasses is the age or growth stage of the plant $(3,15,19)$. At early stages of growth, DM, NDF, ADF, L, C, Si, CF, and NFE contents were lowest while CP, EE, and A contents were highest $(6,7)$. Similar trends in tropical grasses were observed by Arroyo-Aguilú et al. (1) and Arroyo-Aguilú and Rivera-Brenes (2) in CP content; by Arroyo-Aguilú et al. (3) in proximate chemical composition; and by Tessema (19) in CP, $\mathrm{NDF}, \mathrm{ADF}, \mathrm{L}, \mathrm{C}$, and $\mathrm{Si}$ contents. As shown by the simple correlation coefficients $(r)$ presented in table 1 , significant ${ }^{3}$ positive relationships between age and chemical constituents were obtained in order of decreasing values; $\mathrm{DM}, \mathrm{NFE}, \mathrm{L}, \mathrm{ADF}, \mathrm{NDF}, \mathrm{Si}$ and $\mathrm{C}$; significant negative correlations were observed as follows: CP, A, and EE. No significant variations in $\mathrm{H}$ and $\mathrm{CF}$ were obtained as grasses matured.

The $r$ value between NDF content and age was lowest than the one between $\mathrm{ADF}$ and age probably due to the masking effect of the $\mathrm{H}$ content in the NDF fraction. The more positive relationships of the fibrous fractions: $\mathrm{L}, \mathrm{Si}$, and $\mathrm{C}$, with age were responsible for a higher $r$ value in $\mathrm{ADF}$. Similar trends were observed by Tessema (19).

The low correlation (table 1) between $\mathrm{CF}$ and age was probably due to the variable composition of the CF (20). The CF fraction is sometimes more digestible than the NFE, which is supposed to represent the highly digestible carbohydrates (5). As a result, $H$ (14) as well as some $L(13)$ is included in the NFE fraction. This may also explain the positive and highly significant ${ }^{4} r$ value obtained between $\mathrm{NFE}$ and age.

Crude protein was negatively correlated to all parameters except $\mathrm{H}, \mathrm{EE}$ and A. This was expected since, as the fiber fractions increased, CP decreased with an increase in maturity.

Acid-detergent fiber content was correlated in a highly significant way with CF content (table 1). However, a mean difference of 10.6 percentage units was obtained between fiber methods. With increasing growth stages, differences between fiber fractions increased from a low of 7.0 at 30 days to a high of 13.6 units at 180 days of growth. Kim et al. (12) obtained similar results in fiber content of feces, silages and pellets together.

Although highly significant $L$ correlations with NDF and with ADF were higher than with NFE and with CF, suggesting again the large retention of $\mathrm{L}$ in the ADF fraction. The $\mathrm{H}$ content probably pulled down the $\mathrm{C}$ correlation with NDF, leaving a higher $r$ value between $\mathrm{C}$ and ligno-

significant at the 5-percent level.

- Significant at the 1-percent level. 


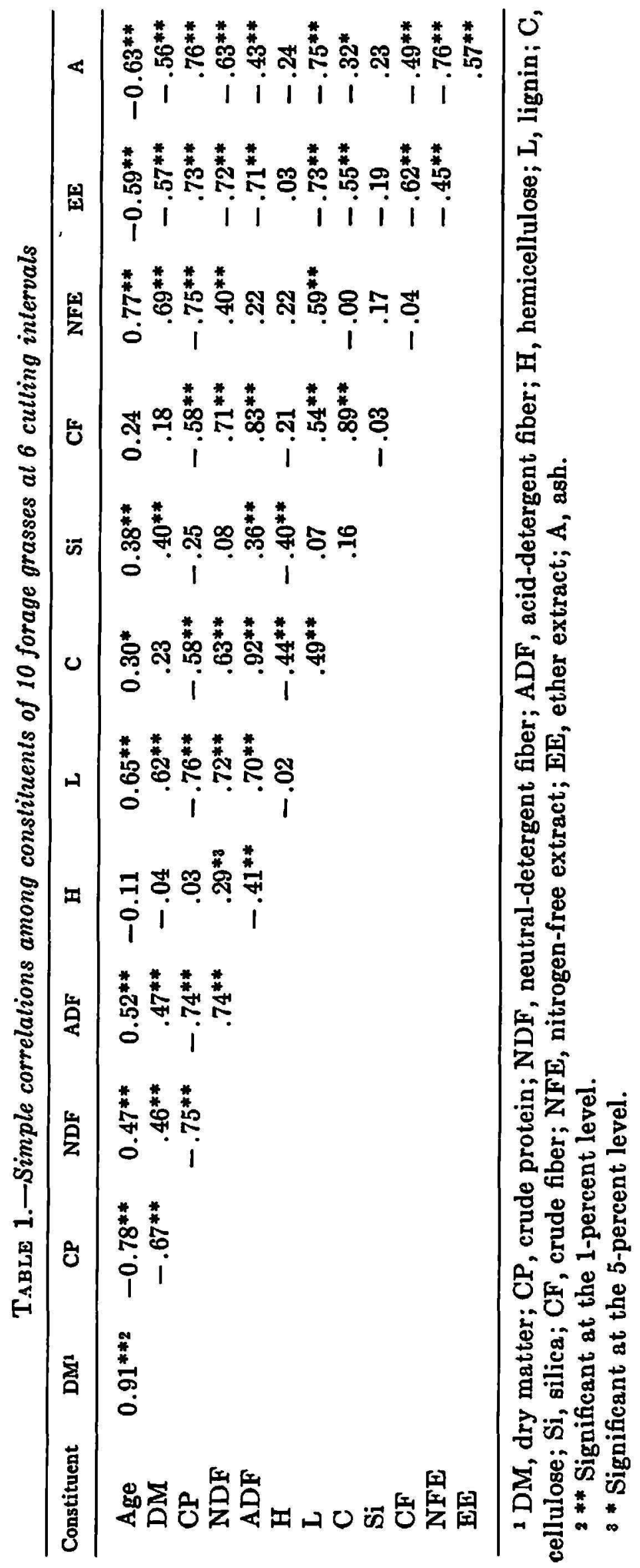


cellulose or ADF. Van Soest (20) suggested that the low NFE digestibility resulted partially from extraction of indigestible $L$ (14) and partially from digestible $H(8)$ in the CF determination.

Silica was significantly correlated (table 1 ) with age, DM, ADF, and $H$ but not with CP, NDF, L, C, CF, NFE, EE, and A. However, the correlations were rather small, suggesting poor predictive value. This is indicative of the fact that $\mathrm{Si}$ content did not increase appreciably as forages advanced in maturity from $\mathbf{3 0}$ to $\mathbf{1 8 0}$ days of growth. The highest mean increase in

TABLE 2.-Regression equations of form $\mathbf{Y}=\mathbf{a}+\mathbf{b X}$ for estimating percent in vitro true digestibility $(\mathbf{Y})$ from physical and chemical constituents $(\mathbf{X})$

\begin{tabular}{lcccc}
\hline $\begin{array}{c}\text { Variables correlated } \\
\text { IVTD' }(Y) \text { with: }\end{array}$ & Intercept & $\begin{array}{c}\text { Coeficient of } \\
\text { regression }\end{array}$ & $\begin{array}{c}\text { Coefficient of } \\
\text { correlation }\end{array}$ & $\begin{array}{c}\text { Standard error } \\
\text { of estimate }\end{array}$ \\
\hline Age & $a$ & $b$ & - & \\
CP & 72.11 & -0.15 & $-0.77^{* * 2}$ & 6.28 \\
NDF & 44.78 & +1.74 & $+.83^{* *}$ & 5.53 \\
ADF & 158.07 & -1.34 & $-.69^{* *}$ & 7.13 \\
L & 126.57 & -1.52 & $-.83^{* *}$ & 5.59 \\
C & 92.03 & -4.57 & $-.80^{* *}$ & 5.92 \\
H & 113.08 & -1.60 & $-.64^{* *}$ & 7.57 \\
Si & 38.36 & +.62 & +.24 & 9.63 \\
L/ADF & 66.54 & -3.68 & $-.40^{* *}$ & 9.10 \\
L/H & 86.91 & -1.81 & $-.54^{* *}$ & 8.36 \\
H/C & 77.19 & -.76 & $-.69^{* *}$ & 7.15 \\
L/C & 31.20 & +.30 & $+.51^{* *}$ & 8.53 \\
CF & 83.81 & -1.23 & $-.56^{* *}$ & 8.19 \\
NFE & 103.82 & -1.34 & $-.57^{* *}$ & 8.12 \\
EE & 103.21 & -.96 & $-.55^{* *}$ & 8.25 \\
A & 34.03 & +13.17 & $+.75^{* *}$ & 6.58 \\
\hline
\end{tabular}

${ }^{1}$ IVTD, in vitro true digestibility; CP, crude protein; NDF, neutral-detergent fiber; ADF, acid-detergent fiber; L, lignin; C, cellulose; $H$, hemicellulose; Si, silica ; $C F$, crude fiber; NFE, nitrogen-free extract; EE, ether extract; $A$, ash.

$2 * *$ Significant at the 1-percent level.

Si content (1.2 units) occurred between 30 and 150 days of growth. Similar correlations between Si with NDF, L and CP were obtained by Smith et al. (16) in New Mexico rangeland forages.

\section{IN VITRO DIGESTIBILITY}

Simple regression equations to predict IVTD from physical and chemical components are presented schematically in table 2 . In vitro true digestibility was correlated in a highly significant way with age, CP, NFD, ADF, $\mathrm{L}, \mathrm{C}, \mathrm{Si}, \mathrm{L} / \mathrm{ADF}, \mathrm{L} / \mathrm{H}, \mathrm{L} / \mathrm{C}, \mathrm{CF}, \mathrm{NFE}, \mathrm{EE}$, and A but not with $\mathrm{H}$. The mean rate of IVTD decline was 24.1 units from 30 to 180 days of age. The 
largest decline (12.3 units) occurred between 30 and 60 days as compared to declines of $4.8,3.9,1.3$, and 1.8 units between 30-day periods from 60 to 180 days. This suggested that forage grasses in the Tropics may be best utilized at stages between 30 and 60 days of growth.

The largest mean decline in CP (8.0 units) and neutral-detergent soluble (7.9 units) fractions also occurred between 30 and 60 days, indicative of the faster protein metabolism at younger stages. Young and rapidly growing plant tissue is higher in CP content than slower growing or more mature tissues (18). The CP decline varied from 4.2 to 15.1 units between species, probably due to species differences in nitrogen uptake and metabolism. Similar differences in CP decline were observed by Tessema (19) in Puerto Rico.

The total fiber or NDF fraction increased with plant maturity, thus reducing IVTD. There was a decline of 2.6 units of digestibility per unit of NDF increase which supports Sullivan's (18) statement that older tissue is more highly lignified and is less digestible than newly formed tissue. Digestibility declined at the rate of 2.2,6.2, and 4.2 units per unit of ADF $\mathrm{L}$, and C, respectively. The correlations between IVTD with NDF, ADF, $\mathrm{L}$, and $\mathrm{C}$ tended to prove it. Similar correlations were obtained by Tessema (19) for all four fractions; Smith et al. (16) for NDF and L; Johnson et al. (11) for NDF; and Weller and Moore (24) for L. Although positive, H seemed to have little association with IVTD. Tessema (19) obtained a similar relationship but in a negative fashion, thus suggesting that $H$ is neither chemically nor nutritionally uniform (22).

The negative effect of $\mathrm{L}$ upon IVTD was observed to be closely related to $\mathrm{L} / \mathrm{H}, \mathrm{L} / \mathrm{C}$, and $\mathrm{L} / \mathrm{ADF}$ ratios (tabie 2). Tessema (19) demonstrated that the main factor influencing $\mathrm{C}$ digestibility was its lignification. Lignin was responsible for the incomplete digestibility of $\mathrm{C}$ and $\mathrm{H}$. This could have occurred via incrustation, but an alternative possibility was through direct linkage of $\mathrm{L}$ to the structural carbohydrates (21). However, $\mathrm{H} / \mathrm{C}$ by itself and not influenced by $L$ exerts a positive highly significant relationship on IVTD. Tessema (19) indicated that, while $H$ was negatively correlated with IVTD, the ratio of $\mathrm{H} / \mathrm{C}$ was positively correlated with IVTD.

The CF fraction, in comparison to the NDF or ADF fraction, was also associated in a highly significant way with IVTD but to a lesser extent. This was probably due to differences in CF composition of the samples, since CF is not a specific substance, nor one chemically uniform (18). The NIE fraction revealed also a highly significant association with IVTD, in the same manner as CF. It was defined by Sullivan (18) as a hypothetica] fraction only, and included all soluble carbohydrates and related substances of the $\mathrm{C}, \mathrm{H}$, and $\mathrm{L}$.

The EE or lipid fraction was correlated in a highly significant way with 
IVTD (table 2). However, lipids are an extremely diverse group, both chemically and physiologically (18). Some lipids are of value as sources of energy or of vitamins; some have no known value to the animals, and some may have functions as yet unknown. Tessema (19) observed that the EE content showed little change either between species or with age within species. The classical EE may have little material significance. Its low EE content and digestibility make it relatively unimportant as an energy source (18).

The A fraction, containing acid-soluble and acid-insoluble (largely $\mathrm{Si}$ ) fractions, was also correlated in a highly significant manner with IVTD. Sullivan (18) indicated that the quantity of A may be misleading as a cri-

TABLE 3.-Simple and multiple regression equations ${ }^{1}$ showing relationships of various chemical constituents to percent in vitro true digestibility

\begin{tabular}{|c|c|c|c|c|c|c|c|c|c|}
\hline \multirow{2}{*}{$\begin{array}{l}\text { Equa- } \\
\text { tion } \\
\text { num- } \\
\text { ber }\end{array}$} & \multirow{2}{*}{ Intercept } & \multicolumn{6}{|c|}{ Coefficient of regression } & \multirow{2}{*}{$\frac{\begin{array}{c}\text { Coefficient } \\
\text { of deter- } \\
\text { mination }\end{array}}{r^{2}}$} & \multirow{2}{*}{$\begin{array}{l}\text { Stand- } \\
\text { ard } \\
\text { error of } \\
\text { estimate }\end{array}$} \\
\hline & & $b_{1}$ & $b_{2}$ & $b_{3}$ & $b_{6}$ & $b_{6}$ & 84 & & \\
\hline 1 & 158.07 & -1.34 & & & & & & $0.48^{* * 2}$ & 7.13 \\
\hline 2 & 119.74 & -.47 & -3.57 & & & & & $.67^{* *}$ & 5.73 \\
\hline 3 & 124.28 & -.42 & -3.53 & -3.08 & & & & $.77^{* *}$ & 4.74 \\
\hline 4 & 103.22 & -.28 & -3.05 & -2.86 & -3.35 & & & $.79^{* *}$ & 4.64 \\
\hline 5 & 78.30 & -.08 & -2.35 & -2.36 & +2.28 & +0.68 & & $.83^{* *}$ & 4.34 \\
\hline 6 & 84.59 & +.13 & -1.98 & -1.66 & -1.54 & +.60 & -0.53 & $.85^{* *}$ & 4.08 \\
\hline
\end{tabular}

${ }^{1} Y=a+b_{1} X_{1}+b_{2} X_{2}+b_{8} X_{8}+b_{4} X_{4}+b_{5} X_{5}+b_{8} X_{6}$, where $Y, X_{1}, X_{2}, X_{3}, X_{4}$, $X_{5}$, and $X_{6}$ are percentages in vitro true digestibility, neutral detergent fiber, lignin, silica, ether extract, crude protein and acid-detergent fiber, respectively.

2** Significant at the 1-percent level.

terion of mineral content, as some Si may be present in a forage as a result of contamination by soil or dust.

Multiple regression analyses are presented in table 3. Of the total variance in IVTD, 85 percent was attributable to the combined influences of $\mathrm{NDF}, \mathrm{L}, \mathrm{Si}, \mathrm{EE}, \mathrm{CP}$, and ADF. Of this total, 19, 10, 2, 4, and 2 units were atrributable to the influences of $\mathrm{L}, \mathrm{Si}, \mathrm{EE}, \mathrm{CP}$, and $\mathrm{ADF}$, respectively, in excess of their joint influences with NDF and L; NDF, L, and Si; NDF, $\mathrm{L}, \mathrm{Si}$, and $\mathrm{EE}$; NDF, L, Si, EE, and $\mathrm{CP}$; and NDF, L, Si, EE, CP, and $A D F$, respectively. The difference between the sum of these variations and 85 percent was 48 percent, attributable to the influence of NDF content. Smith et al. (16) obtained a similar variation (47.71\%) between in vitro organic matter digestibility and NDF in New Mexico range forage grasses.

The multiple regression equations developed (table 3 ): \% IVTD = $84.59+0.13(\% \mathrm{NDF})-1.98(\% \mathrm{~L})-1.66(\% \mathrm{Si})-1.54(\% \mathrm{EE})+$ 
0.60 (\% CP) -0.53 (\% ADF), suggested that IVTD may be predicted with a relatively high precision, as indicated by the highly significant correlation coefficient. However, $\mathrm{ADF}$ and $\mathrm{EE}$ may be deleted since each accounted for only 2 percent of the variation and the decrease in the standard error of estimate was small. From this multiple regression and from the previous simple regressions (table 2), it can be inferred that CP and ADF, or $\mathrm{L}, \mathrm{C}$, and $\mathrm{Si}$, exert the greatest influence upon IVTD.

Multiple regressions to predict IVTD were also developed from $\mathrm{C}, \mathrm{H}, \mathrm{L}$, and $\mathrm{Si}$ (table 4) and from $\mathrm{CP}, \mathrm{C}, \mathrm{L}$, and $\mathrm{Si}$ (table 5). In table 4, it was thus established that 81 percent may be attributable to the influences of $\mathrm{C}, \mathrm{H}$, $\mathrm{L}$, and $\mathrm{Si}$. Of this total, 1, 30, and 9 units would be attributable to the influences of $\mathrm{H}, \mathrm{L}$, and $\mathrm{Si}$, respectively, in excess of their joint influences with C, H; C, H, and L; and C, H, L, and Si. Johnson and Pezo (10) in-

$\mathrm{T}_{\triangle \mathrm{BLE}}$ 4.--Simple and multiple regression equations ${ }^{1}$ showing relationships of various chemical constituents to percent in vitro true digestibility

\begin{tabular}{cccccccc}
\hline $\begin{array}{c}\text { Equation } \\
\text { number }\end{array}$ & Intercept & & Coefficient of regression & & $\begin{array}{c}\text { Coefficient } \\
\text { of deter- } \\
\text { mination }\end{array}$ & $\begin{array}{c}\text { Standard } \\
\text { error or } \\
\text { estimate }\end{array}$ \\
\hline & $a$ & $b_{1}$ & $b_{2}$ & $b_{2}$ & $b_{1}$ & 7 & \\
1 & 113.08 & -1.60 & & & & $0.41^{* * 2}$ & 7.57 \\
2 & 120.76 & -1.68 & -0.17 & & & $.42^{* *}$ & 7.62 \\
3 & 102.69 & -.68 & +.25 & -3.78 & & $.72^{* *}$ & 5.23 \\
4 & 122.20 & -.75 & -.12 & -3.60 & -2.96 & $.81^{* *}$ & 4.39 \\
\hline
\end{tabular}

${ }^{1} Y=a+b_{1} X_{1}+b_{2} X_{2}+b_{2} X_{3}+b_{4} X_{4}$, where $Y, X_{1}, X_{2}, X_{3}$, and $X_{4}$ are percentages in vitro true digestibility, cellulose, hemicellulose, lignin and silica, respectively.

2** Significant at the 1-percent level.

dicated that 64 percent of the variations was attributable to the influences of $\mathrm{C}, \mathrm{H}$, and $\mathrm{L}$, without considering $\mathrm{Si}$.

Table 5 provides the results of multiple regression studies in the first of which 85 percent of the IVTD variation may be attributable to the influences of CP, C, L, and Si. Of this total, 3, 7, and 6 units were attributable to the influences of $\mathrm{C}, \mathrm{L}$, and $\mathrm{Si}$, respectively, in excess of their joint influences with $\mathrm{CP}$ and $\mathrm{C}$; CP, C, and L; and CP, C, L, and Si, respectively. In the other, CP and lignification explained 69 and 7 percent, respectively, of the variation of IVTD.

The following equation (table 5): $\%$ IVTD $=96.85+0.62(\% \mathrm{CP})-$ $0.51(\% \mathrm{C})-2.59(\% \mathrm{~L})-2.34(\% \mathrm{Si})$, best explained and estimated IVTD from chemical composition, as indicated by the smallest standard error of estimate. It indicated that IVTD was increased by 0.62 units for each percentage increase in CP content and decreased by $0.51,2.59$, and 2.34 units for each percentage increase in $\mathrm{C}, \mathrm{L}$, and $\mathrm{Si}$, respectively. Van 
Soest and Jones (23) obtained an average decline of 3 units in dry matter digestibility of temperate forage grasses with each percentage increase in Si content.

These data suggested that IVTD was highly dependent not only upon $\mathrm{CP}$ and lignification, but also upon $\mathrm{C}$ and $\mathrm{Si}$, or $\mathrm{ADF}$, as forage grasses advanced in maturity from 30 to 180 days of growth. It may be concluded that various chemical components of the grasses, namely, CP, C, L, and Si may be utilized to estimate IVTD, without sacrificing accuracy and thus reducing time and cost.

TABLE 5.-Simple and multiple regression equations ${ }^{1}$ showing relationships of various chemical constituents to percent in vitro true digestibility

\begin{tabular}{cccccccc}
\hline $\begin{array}{c}\text { Equation } \\
\text { number }\end{array}$ & Intercept & \multicolumn{3}{c}{ Coefficient of regression } & & $\begin{array}{c}\text { Coefficient } \\
\text { of deter- } \\
\text { mination }\end{array}$ & $\begin{array}{c}\text { Standard } \\
\text { error of } \\
\text { estimate }\end{array}$ \\
\hline & $a$ & \multicolumn{1}{c}{$b_{1}$} & $b_{2}$ & $b_{3}$ & $b_{4}$ & $r^{2}$ & \\
1 & 44.78 & +1.74 & & & & $0.69^{* *}$ & 5.53 \\
2 & 68.15 & +1.44 & -0.61 & & & $.72^{* *}$ & 5.22 \\
3 & 86.36 & +.87 & -.54 & -2.14 & & $.79^{* *}$ & 4.68 \\
4 & 96.85 & +.62 & -.51 & -2.59 & -2.34 & $.85^{* *}$ & 4.06 \\
1 & 44.78 & +1.74 & & & & & $.69^{* *}$ \\
5 & 66.88 & +1.09 & -2.29 & & & $.76^{* *}$ & 4.53 \\
\hline
\end{tabular}

${ }^{1} Y=a+b_{1} X_{1}+b_{2} X_{2}+b_{3} X_{3}+b_{1} X_{4}$, where $Y, X_{1}, X_{2}, X_{3}$, and $X_{4}$ are percentages in vitro true digestibility, crude protein, cellulose in equation 2 and lignin in equation 5, lignin and silica, respectively.

$2 * *$ Significant at the 1-percent level.

\section{SUMMARY}

All parameters of chemical composition and in vitro true digestibility (IVTD) were related by simple and/or multiple correlation and/or regression coefficients in 60 samples of forage grasses representing 10 forages at 6 stages of growth.

Dry matter, neutral-detergent fiber (NDF), acid-detergent fiber (ADF), lignin $(\mathrm{L})$, cellulose $(\mathrm{C})$, silica $(\mathrm{Si})$, crude fiber $(\mathrm{CF})$, and nitrogen-free extract (NFE) were positively correlated while crude protein (CP), hemicellulose $(\mathrm{H})$, ether extract (EE), and ash (A) were negatively correlated with age. Crude protein was negatively correlated with all parameters except $\mathrm{H}, \mathrm{EE}$, and $\mathrm{A}$. Hemicellulose was nore significantly related to the Goering and Van Soest fractions than to the A.O.A.C. fractions. Silica was correlated in a highly significant way with age, DM, ADF, and $\mathrm{H}$ only. In vitro true digestibility was negatively correlated with age, NDF, 
$\mathrm{ADF}, \mathrm{L}, \mathrm{C}, \mathrm{Si}, \mathrm{L} / \mathrm{ADF}, \mathrm{L} / \mathrm{H}, \mathrm{L} / \mathrm{C}, \mathrm{CF}$, and $\mathrm{NFE}$ and positively correlated with $\mathrm{CP}, \mathrm{H}, \mathrm{H} / \mathrm{C}, \mathrm{EE}$, and $\mathrm{A}$.

Multiple regression analyses indicated that, of the total variance in IVTD, 85 percent was attributable to the influences of NDF (48\%), L (19\%), $\mathrm{Si}(10 \%), \mathrm{EE}(2 \%), \mathrm{CP}(4 \%)$, and ADF (2\%). From this regression and from other regressions, it was established that CP and ADF, or $\mathrm{L}, \mathrm{C}$, and $\mathrm{Si}$, exerted the greatest influence upon IVTD. In line with this, it was determined that 81 percent was attributable to. the influences of $\mathrm{C}$ ( $41 \%), \mathrm{H}(1 \%), \mathrm{L}(30 \%)$, and $\mathrm{Si}(9 \%)$ and that 85 percent was attributable to the influences of CP (69\%), C (3\%), L (7\%), and Si (6\%). Finally, it was determined that $\mathrm{CP}$ and lignification explained 69 and 7 percent, respectively, of the influences in IVTD.

These data suggested that IVTD was highly dependent not only upon CP and lignification but also upon $\mathrm{C}$ and $\mathrm{Si}$, or $\mathrm{ADF}$, as forage grasses advanced in maturity from 30 to 180 days of growth. The equation: \% IVTD $=96.85+0.62(\% \mathrm{CP})-0.51(\% \mathrm{C})-2.59(\% \mathrm{~L})-2.34(\% \mathrm{Si})$, best explained and estimated IVTD from chemical composition.

It may be concluded that various chemical components of the grasses, namely, CP, C, L, and Si, may be utilized to estimate IVTD, without sacrificing accuracy and thus reducing time otherwise required and the cost otherwise incurred.

\section{RESUMEN}

Se analizaron estadísticamente por correlación y/o regresión simple y/o múltiple todos los parámetros de composición química y digestibilidad real in vitro (IVTD) en 60 muestras de yerbas forrajeras, que representaban 10 forrajes distintos en 6 etapas de crecimiento.

La materia seca, la fibra neutro-detergente (NDF), la fibra ácido-detergente (ADF), la lignina (L), la celulosa (C), el sílice (Si), la fibra cruda (CF) y el extracto libre de nitrógeno (NFE) se correlacionaron positivamente mientras que la proteina cruda (CP), la hemicelulosa (H), el extracto etéreo (EE) y la ceniza (A) se correlacionaron negativamente, con la edad. La CP se correlacionó negativamente con todos los parámetros excepto el $\mathrm{EE}, \mathrm{la} \mathrm{A}$ y la $\mathrm{H}$. La $\mathrm{H}$ se relacionó más significativamente con las fracciones de Goering y Van Soest que con las del análisis proximal (A.O.A.C.). La Si fue significativamente correlacionada sólo con la edad, la materia seca, la ADF y la H. La IVTD fue negativamente correlacionada con la edad, el NDF, la ADF, la $\mathrm{L}$, la $\mathrm{C}$, el $\mathrm{Si}$, la L/ADF, la L/H, la L/C, la CF y el NFE, y positivamente con la CP, la $\mathrm{H}, \mathrm{la} \mathrm{H} / \mathrm{C}$, el EE y la A.

Las regresiones múltiples indicaron que, de la variación total en la IVTD, el 85 por ciento fue imputable a influencias del NDF (48\%), la L (19\%), el Si (10\%), el EE (2\%), la CP (4\%) y la ADF (2\%). De esta y de otras regresiones se puede establecer que la $\mathrm{CP}$ y la $\mathrm{ADF}$ o la $\mathrm{L}$, la $\mathrm{C}$ y el $\mathrm{Si}$, ejercieron la mayor influencia sobre la IVTD, por lo cual se determinó que el 81 por ciento era imputable a influencias de la C $(41 \%)$, la $\mathrm{H}(1 \%)$, la L $(30 \%)$ y el Si $(9 \%)$ y el 85 por ciento a influencias de la CP $(69 \%)$, la C (3\%), la L (7\%) y el Si $(6 \%)$. Finalmente se determinó que la CP y la 
lignificación explicaron el 69 y el 7 por ciento, respectivamente, de las variaciones en la IVTD.

Estos datos sugirieron que la IVTD dependía en alto grado no sólo de la CP y la lígnificación pero sí también de la $\mathrm{C}$ y el Si o la ADF, seguin las yerbas forrajeras avanzaron en madurez desde los 30 hasta los 180 días. La mejor ecuación para estimar la IVTD de su composición química es la siguiente: $\%$ IVTD $=96.85+0.62(\% \mathrm{CP})$ $-0.51(\%$ C) $-2.59(\% . L)-2.34(\% \mathrm{Si})$.

Se puede concluir que varios componentes químicos de las yerbas, en especial la CP, la C, la L y el Si, pueden utilizarse para estimar la IVTD sin sacrificar la precisión de los datos, reduciendo así el tiempo que de otro modo se requeriría a la vez que el costo en que se incurre.

\section{LITERATURE CITED}

J. Arroyo-Aguilú, J. A., Randel, P. F., Ramirez, A., and Prieto, E., Relación entre proteina cruda y digestible en henos de Pangola (Digitaria decumbens), Estrella (Cynodon nlemfuensis), Guinea (Panicum maximum) y Merker (Penniselum purpureum), abs., Reunión A.L.P.A., Guadalajara, Méx., June 25-30, 1973.

2. - and Rivera-Brenes, L., Relationship between the percentage of crude protein and apparently digestible protein in some forages of Puerto Rico, J. Agr. Univ. P.R. 49: 145-8, 1965.

3. - - - De Arce, M., and Acosta-Matienzo, A., Valor nutritivo y consumo voluntario de las gramíneas Pangola (Digitaria decumbens), Congo (Brachiaria ruziziensis) y Estrella (Cynodon nlemfuensis), A.L.P.A. Mem. 8: 91-106, 1973.

4. Association of Official Analytical Chemists, Official Methods of Analysis, 11th ed., Washington, D.C., 1970.

5. Crampton, E. W., and Maynard, L. A., The relation of cellulose and lignin content to the nutritive value of animal feeds, J. Nutr. 15: 383-95, 1938.

6. Coward-Lord, J., Arroyo-Aguilú, J. A., and Garcia-Molinari, O., Fibrous carbohydrate fractions and in vitro true and apparent digestibility of ten tropical forage grasses, J. Agr. Univ. P.R., 58(3) :293-304, 1974.

7. - - - - - Proximate nutrient composition of ten tropical forage grasses, J. Agr. Univ. P.R., 58(3):305-11, 1974.

8. Ely, R. E., Kane, E. A., Jacobson, W. C., and Moore, L. A., Studies on the composition of lignin isolated from orchardgrass hay cut at four stages of maturity and from the corresponding feces, J. Dairy Sci. 36: 346-55, 1953.

9. Goering, H. K., and Van Soest, P. J., Forage fiber analyses (apparatus, reagents, procedures, and some applications), USDA Agr. Handbook 379, 1970.

10. Johnson, W. L., and Pezo, D., Forage fiber components to predict digestibility, abs., J. Anim. Sci. 37: 296, 1973.

11. Johnson, W. L., Pezo, D., and Justo, G. V., Digestibilidad verdadera in vitro y paredes celulares en alimentos fibrosos, abs., Reunión A.L.P.A. Guadalajara, Méx., June 25-30, 1973.

12. Kim, J. T., Gillingham, J. T., and Loodholt, C. B., Difference in composition between crude fiber and acid-detergent fiber, J. Assoc. Off. Anal. Chem. 50: 340-3, 1967.

13. Norman, A. G., The composition of crude fiber, J. Agr. Sci. 25: 529-40, 1935.

14. Phillips, M., The hemicellulose constituents of the nitrogen-free extract, J. Assoc. Off. Agr. Chem. 23: 119-26, 1940.

15. Reyes, Y., and Sutherland, T. M., Effect of cutting frequency on the in vitro digestibility of some tropical forages during the dry season, Rev. Cub. Cienc. Agric. 3: 175-82, 1969. 
16. Smith, G. S., Nelson, A. B., and Boggino, E. J. A., Digestibility of forages in vitro as affected by content of silica, J. Anim. Sci. 33: 466-71, 1971.

17. Snedecor, G. W., and Cochran, W. G., Statistical Methods, 6th ed., The Iowa State Univ. Press, Ames, Iowa, 1967.

18. Sullivan, J. T., Chemical composition of forages with reference to the needs of the grazing animal, A review of recent research findings, USDA, ARS 34-107, 1969.

19. Tessema, S., Nutritional value of some tropical grass species compared to some: temperate grass species, Ph.D. Thesis, Cornell Univ., 1972.

20. Van Soest, P. J., Nonnutritive residues: A system of analysis for the replacement of crude fiber, J. Assoc. Off. Anal. Chem. 49: 546-51, 1966.

21. - Structural and chemical characteristics which limit the nutritive value of forages, Forage: Economics/Quality, A.S.A. Spec. Publ. 13, 1968.

22. - The chemical basis for the nutritive evaluation of forages, National Conf. on Forage Qual. Eval. and Util., Sept. 2-5, 1969.

23. - , and Jones, L. H. P., Effect of silica on forages upon digestibility, J. Dairy Sci. 51: 1644-8, 1968.

24. Weller, F. E., and Moore, J. E., Técnicas para predecir la calidad de forrajes tropicales, abs., Reunión A.L.P.A., Guadalajara, Méx., June 25-30, 1973. 